\title{
Pola Pendidikan Dan Pengasuhan Generasi Alpha
}

\author{
Ria Norfika Yuliandari \\ UIN Maulana Malik Ibrahim Malang
}

Corresponding author email: fikachu_math@pgmi.uin-malang.ac.id

\begin{tabular}{ll}
\hline & \multicolumn{1}{c}{ Abstrak } \\
\hline Kata Kunci: & Generasi Alpha merupakan generasi penerus dari generasi milenial dan \\
Penerasi Alpha, Pola & generasi Z. Generasi ini lahir ditengah-tengah perkembangan teknologi yang \\
Keluarga. & cukup pesat. Hal ini mengakibatkan mereka telah menerima segala informasi \\
& sejak dini. Dengan penerimaan banyak informasi sejak dini, menjadikan \\
& generasi Alpha dapat berfikir lebih luas dibandingkan generasi sebelumnya. \\
& Sebagai suatu generasi yang menentukan masa depan, maka perlu adanya \\
& perhatian khusus terhadap pola didik serta asuh dari dari orang dewasa \\
& terhadap anak dari generasi ini. Dengan metode kajian literatur, penulis akan \\
& memaparkan pandangan mengenai generasi Alpha dan pola didik serta pola \\
& asuh dari orang dewasa (dalam lingkup keluarga dan sekolah). Pola pendidikan \\
& yang berlandaskan nilai-nilai agama dan nilai-nilai keluarga menjadi hal yang \\
& penting ditengah kemajuan teknologi yang semakin pesat. Serta pola asuh yang \\
demokratis dimana tidak terlalu membatasi keinginan anak atau terlalu & melonggarkan kebebasan anak tetapi orang tua tetap berfungsi sebagai kontrol \\
untuk tindakan anak.
\end{tabular}

\begin{tabular}{ll}
\hline Keyword: & Abstract: \\
Alpha Generation, & The Alpha generation is the next generation of the millennial generation and \\
Education Pattern, & the Z generation. This generation was born in the midst of a fairly rapid \\
Parenting, Family. & from an early age. By receiving a lot of information from an early age, the \\
& Alpha generation can think more broadly than the previous generation. As a \\
& generation that determines the future, it is necessary to pay special attention to \\
& the patterns of upbringing and parenting from adults to children of this \\
& generation. With the literature review method, the author will present views of \\
& the Alpha generation and the patterns of upbringing and parenting of adults \\
& (within the scope of family and school). Education patterns based on religious \\
& values and family values have become important in the midst of increasingly \\
& rapid technological advances. As well as democratic parenting which does not \\
& limit the wishes of the child too much or relax the freedom of the child but the \\
parents still function as a control for the child's actions.
\end{tabular}

@Inventa:Jurnal Pendidikan Sekolah Dasar Copy Right

\section{Pendahuluan}

Generasi Alpha sering dikatakan

sebagai anak dari generasi $\mathrm{Y}$ atau milenial dan adik dari generasi Z. Hampir sebagian besar generasi milenial kini telah menjadi orang tua, sedangkan generasi $\mathrm{Z}$ mulai memasuki fase dewasa muda. Anak-anak dari generasi Alpha merupakan anak-anak yang lahir di tahun 2010 keatas yang pada tahun 2019 ini usia tertuanya adalah 9 tahun. Sebuah lembaga penelitian sosial di Australia 
yang bernama McCrindle, menemukan angka kelahiran generasi Alpha ini telah mencapai laju 2,5 juta kelahiran per minggu (Tim, 2019).

Generasi anak-anak sekarang yang disebut dengan generasi Alpha sangat berbeda dengan generasi-generasi sebelumnya. Hal ini disebabkan karena generasi ini lahir di tengah-tengah majunya teknologi, maka tidak heran jika generasi ini dengan mudahnya terhubung kepada teknologi serta memanfaatkan teknologi tersebut sebagai sarana untuk menggali informasi dan berkomunikasi secara instan. Mereka menghabiskan sebagian waktunya dalam teknologi digital. Menurut Atika (2019), generasi Alpha ini dipercaya dapat tumbuh dan berkembang menjadi generasi yang lebih pintar dibandingkan dengan generasi-generasi sebelumnya. Tetapi perlu diingat bahwa teknologi yang merupakan bagian dari kehidupan manusia, selain memberikan kemudahan, juga dikhawatirkan dapat memberikan dampak negatif terhadap anak anak yang berkaitan dengan perkembangan kognitif, motorik maupun afektifnya. Sehingga tugas keluarga, orang tua maupun sekolah dalam membesarkan dan mendampingi generasi ini pun mempunyai tantangannya tersendiri.

Menurut psikolog anak dan keluarga, Rosdiana Setyaningrum mengatakan bahwa walaupun terlihat identik dengan manusia modern, namun 72 persen generasi alpha masih menyukai untuk bermain di luar ruangan, menyukai kerajinan dan seni, dan sering berinteraksi dengan kakek neneknya yang berada pada generasi baby boomers. Dengan kata lain, teknologi tidak terlalu candu bagi mereka lain halnya dengan generasi milenial dan generasi $\mathrm{Z}$ yang cenderung menyendiri dan berdiam diri di dalam ruangan berpaku pada gadget mereka masing-masing (Rossa dan Rachmawati, 2019). Ibu Khofifah Indar Parawangsa, saat masih menjabat sebagai menteri sosial menyampaikan dalam seminar Nasional bertajuk "Peran Ibu untuk Generasi Alfa" yang diselenggarakan Pengurus Gerakan Perempuan MKGR (Musyawarah Kekeluargaan Gotong Royong) Jawa Timur di Surabaya, menyampaikan bahwa ibu jaman sekarang harus belajar dan mempersiapkan diri untuk mengasuh dan mendidik generasi alpha atau anak ang lahir setelah tahun 2010. Hal ini karena sebagai generasi yang melek teknologi yang serba digital ini tentunya akan sangat berpengaruh terhadap perkembangan anak.

Berdasarkan fakta tersebut, maka pendidikan dan pengasuhan bagi anak-anak dari generasi Alpha ini tentu akan berbeda dengan generasi-generasi sebelumnya. Oleh karena itu, pada tulisan artikel kali ini penulis akan mengkaji bagaimana seharusnya pola pendidikan dan pengasuhan bagi anak-anak dari generasi Alpha kedepannya. 


\section{Hasil dan Pembahasan}

Sebelum membahas bagaimana pola didik dan pola asuh untuk generasi Alpha, ada baik nya berkenalan terlebih dahulu dengan generasi ini. Terdapat beberapa era generasi manusia modern yang diklasifikasikan berdasarkan teori ilmu Sosiologi yakni secara garis besar terdapat dua generasi yaitu generasi perang dan generasi pasca Perang Dunia II. Dari generasi pasca Perang Dunia II inilah kemudian terklasifikasi kembali menjadi enam generasi yakni generasi tradisionalis, baby boomers, generasi $\mathrm{X}$, generasi $\mathrm{Y}$ atau generasi milenial, generasi $\mathrm{Z}$, dan generasi Alpha.

Dilansir dari CekAja, Minggu (24/11/2019), generasi tradisionalis merupakan para manusia yang lahir pada rentang tahun 1992 hingga 1945. Generasi ini merupakan saksi dari berbagai kejadiankejadian besar di dunia. Dikarenakan mereka terbiasa dengan kehidupan dibawah tekanan dan penjajajan, hal ini membentuk jiwa patriotisme yang tinggi dalam hati mereka. Sehingga tidak dipungkiri mereka mempunyai bekal kepemimpinan yang tidak diragukan di dunia kerja. Setelah generasi tradisionalis, maka muncullah generasi yang dinamakan baby boomers. Generasi ini lahir pada kurun tahun 1946 hingga 1964. Dalam kurun waktu tersebut, mereka telah mengalami laju kelahiran yang cukup pesat setelah perlahan pulih dari masa-masa penjajahan dan perang. Para generasi ini cenderung berkecimpung pada pencapaian dalam karir secara konsisten. Generasi baby boomers pun jauh dari era digital sehingga lebih sering menggunakan cara-cara konvensional. Namun demikian, para baby boomers yang masih hidup saat ini mulai akrab dengan gadget.

Selanjutnya adalah generasi X. Tahun kelahiran yang masuk dalam generasi ini yakni tahun 1965 hingga 1980. Pengambilan kata $\mathrm{X}$ disini dipopulerkan oleh novel yang berjudul Generation $X$ : Tales for an Accelerated Culture dan ditulis oleh Douglas Coupand. Generasi ini di Indonesia sendiri dibesarkan dalam keadaan politisi yang cukup memanas dan bergejolak di era pemerintahan Orde Baru. Secara internasional pula, mereka cukup banyak menyaksikan kejadian politik gloal atau konflik seperti pada Perang Vietnam, runtuhnya Tembok Berlin, hingga berakhirnya Perang Dingin. Setelah generasi X, di tahun 1981 hingga 1994, lahirlah generasi $\mathrm{Y}$ atau lebih dikenal dengan generasi milenial. Generasi ini lebih mementingkan eksistensi diri di lingkungan sosial dibandingkan melulu disibukkan dengan pekerjaan. Disamping mengalami perpindahan dari semua yang bersifat analog menjadi digital, generasi ini juga tumbuh seiring tingginya nilai-nilai persamaan dan hak asasi manusia. Generasi milenial ini juga dirasa cukup jeli terhadap peluang dalam bisnis dengan konsep yang lebih inovatif. 
Kemudian pada era tahun 1995-2010, lahir generasi baru yang dinamakan generasi Z. Dengan perkembangan teknologi yang kian hari kian berkembang dengan pesat pada generasi ini, hal ini membuat mereka tak mampu lepas dari gadget dan aktivitas sosial media lainnya. Dikarenakan kecanduan mereka terhadap gadget ini, membuat mereka dengan lebih cepat menemukan informasi terbaru dibandingkan generasi-generasi sebelumnya. Bagi generasi Z, teknologi dapat melakukan apa saja baik itu belajar atau bekerja selain hanya untuk bersenang-senang.

Generasi terakhir merupakan generasi Alpha atau merek yang lahir di tahun 2010 keatas. Generasi ini lahir di era teknologi yang telah berkembang sangat pesat. Namun tidak seperti dua generasi sebelumnya, generasi ini cenderung tidak terlalu candu terhadap gadget. Mereka yang lahir pada generasi ini telah menerima teknologi sejak di usia belia, maka tidak dipungkiri lagi generasi ini diyakini sebagai generasi hebat di masa mendatang.

Dilansir dari Matranews, Sabtu (12/10/2019), generasi Alpha saat ini dikenal sebagai generasi yang paling berpengaruh pada kehidupan manusia. Hal ini diukur dengan usia mereka yang sangat dini, namun dapat memengaruhi perputaran perekonomian dunia. Untuk karakteristik generasi ini masih belum diketahui dengan pasti dikarenakan usia tertua dari generasi ini baru mencapai usia 9 tahun. Walaupun demikian, sudah banyak asumsi-asumsi yang menggadang-gadang bahwa generasi ini akan lebih terdidik dan lebih sejahtera dibandingkan generasi Z. Untuk mencapai tujuan tersebut maka tidak perlu disanggah lagi bahwa peranan orang tua dalam menentukan pendidikan dan pola asuh terhadap generasi ini sangatlah penting.

\section{Pendidikan Dan Pengasuhan Anak dalam}

\section{Keluarga}

Pendidikan merupakan satu hal yang penting dalam kehidupan manusia. Pendidikan dalam arti yang luas dimaknai sebagai semua pengalaman dalam hidup yang dapat membawa pengaruh positif bagi suatu individu (Buasim, 2014). Dalam arti luas ini pun pendidikan dapat dilakukan di mana saja, kapan saja, dan oleh siapa saja. Pendidikan tidak terbatas hanya di dunia sekolah, karena pendidikan ini akan terus berlangsung hingga akhir hayat. Pendidikan pun dapat terjadi di lingkungan keluarga dan masyarakat (Rupert, 2003). Keluarga merupakan tempat atau media utama seorang anak memperoleh pendidikan. Anggota keluarga terdiri ayah, ibu, dan anak, dimana masing masing keluarga mempunyai fungsi dan peran tersendiri. Ayah dan ibu sebagai pendidik pertama dalam proses perkembangan kehidupan seorang anak. Orang tua tidak hanya berperan sebagai pemberi kasih sayang atau sekedar memenuhi kebutuhan materiil anak-anaknya, tetapi lebih dalam lagi, keluarga berperan penting untuk menciptakan 
suasana dalam keluarga suatu proses pendidikan yang berkelanjutan. Proses pendidikan yang berkelanjutan ini bertujuan untuk melahirkan generasi penerus bangsa yang berakhlak, berbudi pekerti yang baik, baik dimata orang tua dan masyarakat. Menurut Berns (2007, 89-90), mengemukakan lima fungsi keluarga, yang diantaranya adalah (1) fungsi reproduksi, (2) fungsi pendidikan dan sosialisasi dimasyarakat, (3) membangun aturan-aturan sosial, (4) melakukan tindakan ekonomi, dan (5) membangun dan mendukung proses perkembangan emosi anak.

Sementara, ahli lainnya, yaitu Mollehnhaur (dalam Abdullah, 2003:2037), membagi fungsi keluarga dalam perkembangan pendidikan anak menjadi tiga fungsi. Pertama, fungsi kuantitatif, berkaitan dengan pemenuhan kebutuhan bagi pembentukan perilaku dasar. Artinya, keluarga tidak hanya memenuhi kebutuhan dasar fisik anak dalam bentuk makan dan minum, tempat tinggal yang layak. Tetapi juga mempunyai kewajiban memenuhi dan memfasilitasi dasar-dasar kebaikan, perubahan perilaku, etika, sopan santun, berkarakter dan beraklhak yang baik. Kedua, fungsi selektif yang berkaitan dengan keluarga sebagai fungsi kontrol dan pengawasan terhadap semua informasi yang diterima anak. Hal ini mengingat di masa kanak-kanak, mereka tidak dapat membedakan mana yang baik dan buruk.
Ketiga, fungsi pedagogik yang artinya keluarga harus mewariskan nilai-nilai yang berkaitan dengan aspek kehidupan anak. Hasil akhir dari pendidikan keluarga akan tercermin dari sikap dan perilaku yang ditunjukkan oleh anak dalam kehidupan sehari-hari. Pentingnya peran dan fungsi keluarga keluarga dalam perkembangan anak, karena lingkungan keluarga merupakan lingkungan pertama yang ditempati oleh anak sebelum ia mengenal dunia luar. Hal ini sejalan dengan pernyataan Purwanto (2003), ia menyatakan bahwa pendidikan keluarga merupakan basis atau dasar dari semua pendidikan yang anak peroleh, serta keluarga juga yang akan menentukan pendidikan anak setelahnya baik di sekolah ataupun di lingkungan masyarakat.

Perlu diketahui bahwa anak bukanlah orang dewasa dengan perbandingan ukuran yang kecil. Dengan demikian, seorang anak sangat perlu diperlakukan sesuai dengan tahap-tahap perkembangannya. Namun kenyataan yang ada menunjukkan sebaliknya, banyak di sekeliling kita baik orang tua ataupun masyarakat dalam memperlakukan anak tidak sesuai dengan tingkat perkembangannya. Dalam pendidikannya sendiri dalam perkembangan anak, banyak pengajar yang menggunakan tekanan dimana hal tersebut sangat tidak sesuai dengan tahap perkembangan anak (Adrianti, 2011). Sehingga makna pendidikan tidak hanya untuk menyekolahkan anak agar 
mendapatkan ilmu yang bermanfaat. Namun secara garis besar, dengan memperoleh pendidikan yang lengkap, seorang anak dapat tumbuh dan berkembang dengan lebih baik sehingga ia pun dapat menjadi manusia yang berguna bagi nusa dan bangsa (Anhusadar, 2016). Dengan demikian dalam mendidik seorang anak sangat perlu sejak dini, hal ini dikarenakan masa anak-anak merupakan masa keemasan (golden age) yang kelak akan menentukan masa depan anak itu sendiri. Oleh karena itu, selain potensi yang dimiliki seorang anak, peran orang tua sangat dibutuhkan dalam menentukan tumbuh kembang anak.

Masing-masing orang tua memiliki caranya sendiri dalam mendidik anak-anak mereka. Namun perlu diperhatikan bahwa faktor penting dalam pendidikan keluarga yakni pengertian orang tua terhadap kebutuhan jiwa anak sehingga dapat menciptakan lingkungan serta suasana yang kondusif yang nantinya akan menjamin pemenuhan kebutuhan pokok anak. Selain memperhatikan aspek pendidikan anak, keluarga atau dalam hal ini lebih ditekankan pada orang tua juga perlu memperhatikan pola asuhan mereka terhadap anak mereka. Menurut Kohn pola asuh merupakan sikap orang tua ketika berhubungan dengan anak mereka. Sikap ini pun dapat dilihat dari beberapa aspek, mulai dari tata aturan yang dibuat orang tua untuk anak mereka, cara orang tua memberi apresiasi atau hukuman terhadap anak, cara orang tua menunjukkan otoritasnya atau bagaimana orang tua dalam memberikan perhatian terhadap anak mereka serta bagaimana penanggapan orang tua terhadap keinginan anak mereka (Thoha, 1996).

Menurut Baumrind yang dikutip oleh Muallifah (2009:42), pola asuh pada prinsinya merupakan parental control yakni bagaimana orang tua mengontrol, membimbing, dan mendampingi anakanaknya untuk melaksanakan tugas-tugas perkembangannya menuju pada proses pendewasaan. Sementara menurut Heterington dan Porke (1999) yang dikutip oleh Sanjiwani, pola asuh merupakan bagaimana cara orang tua berinteraksi dengan anak secara total yang melipuyi proses pemeliharaan, perlindungan dan pengajaran bagi anak. Berdasarkan pengertian tersebut dapat disimpulkan bahwa memberikan pola asuh yang baik dan positif akan menciptakan konsep diri yang positif bagi anak. Dalam pola asuh sendiri, masing-masing orang tua mempunyai caranya tersendiri. Secara umum, orang tua sering menggunakan pola asuh yang mereka dapatkan sebelumnya yang mereka rasa berhasil. Pemilihan pola asuh tentu akan menentukan karakter anak kedepannya. Beberapa ahli membagi tiga pola asuh, yakni pola asuh otoriter, demokratis, dan permisif (Yatim dan Irwanto, 1991). Sementara Dariyo (2004:97), membagi pola suh menjadi 3 pola, yakni: 
1) Pengasuhan otoriter. Orang tua dengan gaya pengasuhan ini membatasi dan memberikan hukuman kepada anak ketika anak melakukan kesalahan yang tidak sesuai dengan keinginan orang tua. Anak yang dibesarkan dengan pola asuh ini cenderung tidak bahagia karena merasa tertekan dengan aturan dan ketakutan dengan hukuman serta kemampuan komunikasi yang lemah karena tidak terbiasa menyampaikan pendapat.

2) Pengasuhan demokratis. Ciri khas gaya pengasuhan tipe ini adalah orang tua memberikan kebebasan kepada anak tetapi orang tua tetap berfungsi sebagai kontrol untuk memberi batasan dan kendali terhadap tindakan anak. Anak yang diasuh dengan gaya pengasuhan demokratis ini cenderung mandiri, dewasa dan dapat mengendalikan diri dengan baik.

3) Pengasuhan permisif. Gaya pengasuhan dimana orang tua memberikan kebebasan penuh terhadap apa yang dilakukan anak tanpa pengawasan. Hal ini karena orang tua sama sekali tidak terlibat dalam kehidupan anak anak sehingga anak dengan gaya pengasuhan permisif cenderung melakukan pelanggaran-pelanggaran yang ada.
4) Pengasuhan situasional. Orang tua yang sangat terlibat dengan anak, tidak terlalu menuntut dan mengontrol sehingga membiarkan anaknya melakukan sesuka hati. Akibatnya anak akan tumbuh menjadi pribadi yang tidak dewasa dan manja serta kesulitan berhubungan baik dengan teman sebayanya.

Sehingga dari sini dapat kita simpulkan bahwa hakikat dari pendidikan dan pengasuhan anak adalah apa yang diberikan dan diajarkan orang tua atau keluarga. Dimana hal tersebut sangat menentukan tumbuh kembang anak di masa mendatang. Pada dasarnya pendidikan anak tidak hanya berada pada lingkungan sekolah saja, namun pendidikan dasar yang perlu diperhatikan untuk anak adalah pendidikan keluarga. Sejalan dengan pendidikan yang berhasil dalam keluarga, maka pola asuhan yang baik dalam keluarga pun akan sangat menunjang perkembangan anak.

\section{Pendidikan Dan Pengasuhan Bagi Generasi Alpha}

Sebagaimana yang telah penulis paparkan mengenai generasi Alpha tersebut, maka sangat perlu diperhatikan bagi para orang tua atau calon orang tua untuk dapat mendidik dan mengasuh anak mereka yang lahir pada generasi ini dengan sebaikbaiknya. Dikarenakan generasi ini masih belum dapat diketahui karakteristiknya, namun dari beberapa artikel dikatakan bahwa 
generasi ini dapat menyeimbangkan antara teknologi dan bermain, tidak seperti pada generasi $\mathrm{Y}$ dan generasi $\mathrm{Z}$ yang terlalu candu terhadap gadget.

Perhatian penting yang perlu dipersiapkan oleh para orang tua adalah membantu pemanfaatan teknologi dengan benar bagi anak mereka. Hal ini dikarenakan mereka lahir ditengah-tengah perkembangan teknologi yang pesat, pemilihan pola asuh dan didikan yang benar akan membawa anak pada generasi ini menuju kesuksesan yang lebih matang dari generasi sebelumnya. Namun, jika pemilihan pola asuh dan didikan yang salah, maka akan mengakibatkan anak terjerumus pada gemerlapnya teknologi. Sebagai pendidikan dasar dalam kehidupan, keluarga atau orang tua juga perlu terus memfasilitasi setiap potensi anak. Dikarenakan mereka telah dipaparkan oleh informasi sejak dini, maka akan lebih mudah bagi para orang tua untuk dapat menemukan kemampuan atau keahlian khusus pada generasi Alpha ini. Para orang tua juga perlu untuk membimbing anak agar belajar terus menerus sesuai potensi yang dimiliki anak. Dengan konsistensi ini, maka anak dari generasi Alpha ini akan tumbuh hebat dengan bakatnya dan mempunyai kemampuan juang yang tinggi. Selain itu, menanamkan norma agama sejak dini menjadi hal utama yang harus diperhatikan oleh para orang tua. Norma agama akan membentengi anak dalam masa perkembangan mengenal dunia.
Selanjutnya yang tidak kalah penting adalah mengajarkan sopan santun, nilai-nilai karakter yang positif serta bersosialisasi melalui pembiasaan-pembiasaan yang dimulai dari lingkungan keluarga. Yang terakhir adalah menanamkan nilai keluarga kepada anak sejak dini. Setiap keluarga mempunyai nilai-nilai baik yang berbeda antara keluarga satu dengan yang lainnya, tetapi mempunyai satu tujuan yang sama yaitu memberikan contoh yang baik pada anakanaknya sehingga anak dapat menghargai nilai positif yang ada dalam keluarganya dan menjalankannya dengan hati terbuka.

Selain itu, orang tua perlu mengatur pola asuhan secara demokratis, artinya tidak terlalu membatasi keinginan anak atau terlalu melonggarkan kebebasan anak. Pembuatan aturan yang sebelumnya dimusyawarahkan dalam keluarga tetap perlu untuk melatih kedisiplinan anak tanpa mengurangi rasa terkekang dalam diri anak. Hal ini tentu saja dengan memperhatikan informasi-informasi yang diperoleh anak sejak dini membuat mereka dapat berpikir lebih luas dari berbagai hal.

\section{Kesimpulan}

Generasi Alpha merupakan generasi yang lahir ditengah-tengah perkembangan teknologi yang sangat pesat. Sehingga hal ini membuat mereka telah menerima beragam informasi sejak usia belia. Pemilihan pola asuh bagi generasi ini sangat penting, karena generasi digadang sebagai generasi maju di 
masa mendatang. Sehingga peran orang tua dalam hal pendidikan pertama bagi generasi ini serta pola asuh yang diberikan akan sangat menentukan bagaimana jadinya generasi ini kedepannya. Sebagai saran untuk penulisan selanjutnya dapat menambahkan karakteristik yang lebih khusus mengenai generasi Alpha, sehingga akan dapat menentukan pola didik serta asuh yang tepat bagi generasi ini.

\section{Daftar Pustaka}

Abdullah, M. Imron. 2003. Pendidikan Keluarga Bagi Anak. Cirebon: Lektur.

Adrianti. 2011. Partisipasi Orang Tua Dalam Pengelolaan Pendidikan Anak Usia Dini (Studi Deskriptif Pada Paud Binaan Bpkb Provinsi Gorontalo). Jurnal Pendidikan Luar Sekolah. Vol. 7, No. 1 tahun 2011 diakses pada tanggal 17 November 2019.

Anhusadar, La Ode. 2016. Kreativitas Pendidik di Lembaga PAUD. Jurnal Al-Ta'dib. Vol. 9, No. 1 tahun 2016 diakses pada tanggal 17 November 2019.

Atikha.

2019.

https://id.theasianparent.com/generasi -alpha-adalah. Diakses pada Senin 18 November 2019 pukul 08.27 WIB.

Berns, Roberta M. 2007. Chil, Family, School, Community Socialization and Support. United State: Thomshon Corporation.

Buasim. 2014. Strategi Pembelajaran TK. In: Hakikat Pendidikan dan Pembelajaran di Taman Kanak-kanak. Universitas Terbuka, Jakarta, pp. 128.
Dariyo, Agus. 2004. Psikologi Perkembangan Remaja. Galia Indonesia: Bogor Selatan.

Muallifah. 2009. Psycho Islamic Smart Parenting. Diva Press.

Rossa, Vania dan Rachmawati, Dinda. 2019 https://www.suara.com/health/2019/0 9/19/192056/sama-sama-akrabdengan-teknologi-ini-beda-generasialpha-dengan-milenial. Diakses pada Senin 18 November 2019 pukul 09.59 WIB.

Rupert S. Lodge Syarifudin. 2003. Proses Belajar Mengajar. Bumi Aksara: Jakarta.

Sanjiwani, Putu Y dkk. 2014. Pola Asuh Permisif Ibu Dan Perilaku Merokok Pada Remaja Laki-Laki di SMA Negeri I Semarapura, Jurnal Psikologi Udayana, vol. 1, no. 2, 2014. Diakses pada tanggal 20 November 2019.

Thoha, C. 1996. Kapita Selekta Pendidikan Islam. Yogyakarta : Pustaka Pelajar (IKAPI)

Tim CNN Indonesia. 2019 https://www.cnnindonesia.com/gayahidup/20190812144950-284420574/mengenal-gen-alphagenerasi-setelah-milenial-dan-gen-z. Diakses pada Senin 18 November 2019 pukul 07.58 WIB.

Yatim D.I., dan Irwanto. 1991. Kepribadian Keluarga dan Narkotika. Jakarta: Arcan.

https://matranews.id/generasi-alpha-apa-itu/

https://www.cekaja.com/info/milenial-serta$\underline{\text { 5-generasi-sebelum-dan-sesudahnya/ }}$

https://www.kominfo.go.id/content/detail/12 175/mensos-ibu-zaman-now-harussiap-mengasuh-generasi-alfa/0/berita 